DE DE GRUYTER OPEN
Research Article

C 2018 Ivana Bulog and Ivan Grančić This is an open access article licensed under the Creative Commons Attribution-NonCommercial-NoDerivs License (http://creativecommons.org/licenses/by-nc-nd/3.0/).

\title{
The Benefits of Business Ethics - Ethical Behavior of Decision Makers: the Empirical Findings from Croatia
}

\author{
Ivana Bulog \\ PhD, Assistant professor, \\ University of Split, Faculty of Economics \\ Ivan Grančić \\ University of Split, Faculty of Economics
}

Doi: $10.2478 / \mathrm{mjss}-2018-0067$

\begin{abstract}
More than ever before, the ability of managers to recognize and deal with complex business ethical issues has become a significant priority. Ethical behavior has always been a concern for managers because they are the ones that have major responsibility in company when it is about business ethics. Managers' work is manly the work of making decisions. On a daily basis they are making decisions - big and small ones - on which company future depends. Interest in business ethics and ethical behavior is on the rise, especially in recent years when widespread moral corporate scandals have brought this topic to the fore. Therefore, the organizational environment demands effective managers - decision makers -with the ability to behave ethically and the ability to make right choices. There is no doubt that the ethical behavior of decision makers is of strategic importance for successful business. It could be acknowledged that among the numerous different factors that can determine a company's progress, the key elements that contribute to a more successful achievement of company competitive advantage is the ethical behavior of managers. This paper aims at analyzing the benefits of business ethics and at identifying the ethical behavior of managers in a big company in Croatia. Qualitative research was conducted and interesting and somewhat puzzling results were found. Based on the overall findings, this research offers the foundation for future research in this area. The implications of the findings are discussed in terms of value for managers and their companies due to the improvement and development of business ethics and their ethical behavior.
\end{abstract}

Keywords: Business Ethics, Ethical Behavior, Decision Making

\section{Introduction}

Managers, employees and individuals as non-professionals are facing, on a daily basis, with some doubts, ambiguities and choices among many different options that require ethics in action. In a business environment, decisions must be taken quickly, under time pressure which does not leave much room for rational judgment. Competition, public, superiors, employees, state organs, private life... all these are concepts that should be taken into account when a certain business decision is made. In such complex circumstances, it is very difficult to think about ethics of every decision. Thus, ethical behavior even more complicates decision making situations.

It is quite clear that decision making is not an easy process for managers. There is no doubt that managers are facing a number of ethical challenges in their everyday activities, trying to respond better to all the demands of all stakeholders with whom they are directly and indirectly linked. Today, ethical behavior of decision makers is of strategic importance for a successful business. It could be acknowledged that the key element that determines the company's progress 
is the ethical behavior of managers.

In order to achieve overall satisfaction in the company, before deciding, the decision should be afforded the ethical principles of all interest groups. It is almost sure that certain problems will occur during the decision making process, but nevertheless, these problems should not influence company management in a way that they abandon ethical behavior. On the contrary, these kinds of situations should encourage and inspire managers to find a quality and ethical solution in a creative and reliable way.

Today, more than ever before, the ethical behavior of manager has become a significant priority. Interest in business ethics and ethical behavior is on the rise, especially in recent years when widespread moral corporate scandals have brought this topic to the fore. Therefore, the organizational environment demands effective managers - decision makers -with the ability to behave ethically and the ability of making right choices.

This paper aims at analyzing the benefits of business ethics and at identifying and analyzing the ethical behavior of managers in a company in Croatia. The importance of this research is its potential to contribute to the existing knowledge of a manager's ability to behave ethically. Moreover, results could be important to the managers of the analyzed company because they will become familiar with employees' perspective about their ethical behavior in the workplace.

A review of the literature has revealed that research into business ethics in the Republic of Croatia is insufficiently represented on the macro and micro level (Ivaniš and Šturlić, 2016). Bearing in mind that the general attitude prevails that companies in Croatia pay insufficient attention to business ethics and given the fact that this topic is relevant, but not researched enough from an empirical viewpoint, this research is welcome and justified both from a scientific as well as from a practical perspective.

\section{Ethical Behavior of Decision Maker}

Drucker (1954) described ethical behavior as a reflection process and a communal exercise that concerns the moral behavior of individuals based on an established and expressed standard of individual values. Further, Suhonen et al., (2011) described ethical behavior as acting in ways consistent with what society and individuals typically think are good values.

Ethics should apply to every individual in an organization, but ethical behavior is an absolute requirement of all organizational leaders - managers (Emery, 2016). Nevertheless, ethics should apply to all situations, regardless of status (Drucker, 1954).

Managers are the ones who make crucially important decisions for the company's future. In fact, management realizes its role by deciding (Sikavica et al., 2004). It is not hard to imagine that making right decisions can be extremely complicated for managers when facing moral dilemmas in business. Managers have a responsibility to uphold the highest standards of ethical conduct which involves relating ethical behavior to a leader's ability to make sound decisions (Li \& Madsen, 2011), while sound decision making defines the scope of the leader's responsibility, which makes leaders accountable for determining what they must appraise and judge to protect the organization from unethical behavior (Toubiana \& Yair, 2012) (In: Emery, 2016).

Primarily, managers' familiarity with ethical principles and ethical frameworks is the foundation for ethical behavior. Ethical decision making is conditioned by numerous facts and factors (Buble, 2006) that decision makers should take into account when making decisions. For that reason, it is necessary to create an ethical framework in the organization to facilitate most situations. Ethical frameworks are products of the ethical codex of the organization (Jelšenjak and Krkač, 2016). Within ethical frameworks, managers would know, in a large number of cases, whether some of potentially problem-solving variants are ethical or not.

Decision makers can learn how to avoid ethically dangerous zones (Bazerman, Messick and Stewart, 2007) and thus become significantly more efficient. They can learn how to make an ethical decision by using certain learning tools and following some ethical principles. In that way, managers are able to make decisions that are consistent with socially responsible behavior what can reflect positively on employee satisfaction and consequently results in overall business success. Social responsibility is a belief in the notion of shared responsibility for the common good (Stanaland, Lwin 
and Murphy, 2011). It is a business's obligation to maximize its positive impact and minimize its negative impact on society (Ferrel, Fraedrich and Ferrell, 2005).

A successful manager is considered the one who, by his/her own example, constantly shows what it means to act ethically, creating such an atmosphere in relationship with employees that enable him/her to develop objectivity and responsibility in decision making (Sikavica et al., 2004). An effective manager is the one who, from day to day, deliberately teaches employees and colleagues what ethics are and how important it is in the overall business activities of the company. Formally defined, ethical behavior is morally accepted as "good" and "right" as opposed to "bad" and "wrong" in a particular surrounding (Ivaniš and Šturlić, 2016).

\section{The Benefits of Business Ethics}

The acceptability of behavior in business is determined by customers, competitors, government regulators, interest groups, and the public, as well as each individual's personal moral principles and values (Ferrel, Fraedrich and Ferrell, 2005).

Today, in the contemporary business environment full of changes and competitors, each company meets numerous obstacles if their business plan is not based on business ethics. Business ethics relates to an individual's or a work group's decisions that society evaluates as right or wrong (Ferrel, Fraedrich and Ferrell, 2005). Aleksić (2007) defines business ethics as a system of basic values and rules of individual, organizational and social behavior associated with business and business goals (Aleksić, 2007). Business ethics is also defined as ethical judgment in business situations and activities. The importance of business ethics in the first place is the fact that customers and consumers consciously and subconsciously perceive businesses as ethical or not ethical. This fact is more than enough for companies' to start with ethical business.

Business ethics has become one of the key factors differentiating successful from unsuccessful companies. Doing business ethically means to work according to the letter of the law, perform duties on time and put consumers and customers as priorities. To apply business ethics means thinking about others, thinking about the future. Companies with business ethics had previously developed long-term plans and goals. Business ethics gives a sense of security and opportunity for future development. It must be emphasized that business ethics is essential in every business situation, with no exceptions (Bazerman, Messick and Stewart, 2006). Ethical companies will abnegate short-term profit to have a long-term positive image in the eyes of the public. By operating in this way, the company creates a positive climate, growing confidence and the possibility of constant progress. These kinds of companies have a great advantage over the non-ethical ones.

Business ethics is one of the types of means of differentiation because there are only a small number of companies which fully applies and uses its many benefits. Among numerous reasons Ferrel, Fraedrich and Ferrell (2005 p. 31) point out these for a strong commitment to ethical values:

1. Ethical companies have been shown to be more profitable.

2. Making ethical choices results in lower stress for corporate managers and other employees.

3. Our reputation, good or bad, endures.

4. Ethical behavior enhances leadership.

5. The alternative to voluntary ethical behavior is a demanding and costly regulation.

An ethical codex in organizations, which is interpreted as the foundation of business ethics, is also extremely important (Jelšenjak and Krkač, 2016). Business ethics is becoming increasingly important in companies because it allows them to efficiently respond to needs of all stakeholders customers, employees, shareholders and society as a whole. Today, a growing number of companies focus on the adoption of ethical values and ethical standards as a fundamental component of business ethics. The business world is so complex that companies need to constantly show potential clients, investors and partners that the organization is a moral subject who cares and takes into consideration the whole society and has a kind of social mission.

\section{Methodology}

The purpose of this paper is to examine and identify the ethical behavior of managers (decision - 
makers) in a company in Croatia. In order to carry out analysis, a questionnaire was used. The questionnaire included 27 statements about the ethical behavior of managers. These statements were divided into three segments. The first part of the questionnaire considered the relationship between managers and subordinates (employees); the second part considered manager traits as professional in his/her position, while the third part was dedicated to the relationship between manager and company - how they perceive their company. This survey was oriented on employee views on the ethical behavior of decision makers in the company. The company consists of 5 different departments: IT department, human resource department, accounting department, purchasing department and marketing department. Departments are led by managers, thus 5 different managers were evaluated. 15 employees evaluated each department manager. They were asked to follow a Likert's scale with five levels of intensity, ranging from "I strongly disagree" to "I strongly agree" when evaluating each statement.

The questionnaires were distributed before the work shift when employees were rested and had a high level of concentration. The time for thinking was unlimited so every respondent could take enough time to evaluate each of the five managers. The process of evaluation was very positive; the respondents were polite and pleased to provide their own opinion on their superiors.

\section{Findings}

The empirical results of this research were as follows. Managers with a total score between 30 and 35 points were appraised as being highly ethical and reliable managers, whom every employee can trust and rely on. Managers with a score between 36 and 61 points were valued as managers who in certain situations show unethical behavior, while managers with a score between 62 - 108 points were appraised as managers who behave unethically and who will in the long run bring poor results to the company.

As represented in Figure 1, employees rated the IT department manager as the most ethical in their company. Although rated as the most ethical (with an average score of 45 points), he leans more towards the category of average ethical behavior while making decisions. This means that in certain situations he is behaving unethically when making decisions. All respondents are convinced that this manager will be reluctant to behave unethically even if it brings him certain profit or benefit.

Following him is the marketing department manager. He was rated somewhat weaker (51 points), but he is in the same category as the previous manager - average ethical behavior while making decisions. The third manager in regard to total score is the accounting department manager with an average score of 60 points. He is actually somewhat in between average ethical and unethical behavior. The last two managers were evaluated as extremely unethical in their behavior. Namely, the manager of the purchasing department was rated with an average score of 69 points representing the one to whom ethical behavior does not mean much. Employees described him as an unreliable and selfish person, although possessing the knowledge and quality of working tasks.

The worst rated manager is the human resource department manager. This manager was awarded an average of 74 points which represents an extremely unethical result. All respondents are convinced that he has employed people who are not qualified for the position that they hold. Whether this is true and how much this harm the company will remain unknown, but one thing is for sure, this manager must realize the importance of ethics in business. 


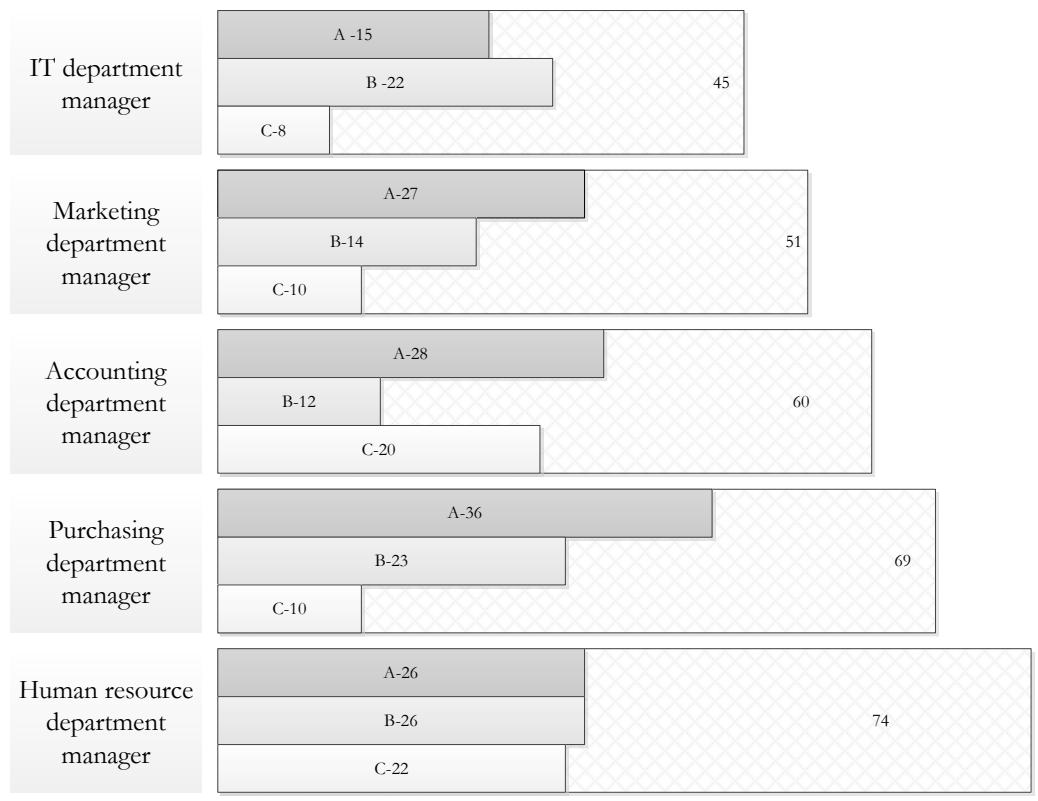

Figure 1: Ethical behavior of decision makers in the company

Source: Empirical results

If each part of ethical behavior is observed separately, it is noticeable that the most ethical behavior is the one regarding the relationship with the company, meaning that managers value the company and respect organizational rules. The least ethical is the relationship with employees (subordinates), meaning that managers are very poorly and improperly relating to subordinates. It is unknown what the real reason is for this is, but according to the questionnaire statements, it can be concluded that this manager views all associates as competitors and that most important to him is the personal reputation of the company. The manager of the purchasing department in the first category had a high rating of 36 points indicating that he has an absolutely wrong, improper and unprofessional relationship with subordinates. Employee comments indicated experiences of manger humiliation and demotivation. Among employees this is the most unpopular manager.

As far as the overall employee impression is concerned, the problem of collective thinking prevails in this company. Individuals, who can in some way influence the outcome of a particular decision, simply do not want to express their opinions if it is against the majority or their superiors. This company often experiences the worst that can happen in the overall decision-making process deliberately making the wrong decisions. The only positive about this company is that it does not actually have a direct competitor on the market. It seems that every manager in this company is constantly criticizing employees, which is not good at all for the atmosphere in the company. Thus, this reflects negatively on employees' attitude towards work. Also, employees have in common the attitude that mangers would fire workers they do not like personally for various reasons, regardless of their professionalism.

Research results show that this company does not have developed business ethics. This research indicates that managers in everyday decision making tend to neglect ethics. There are no ethic principles or codes in the company, there are no departments for business ethics, and employees are not educated about the importance of ethics for business. Consequently, this company has yet to understand the importance of ethics and ethical behavior. 


\section{Conclusion}

In a contemporary business environment, where making profit appears to take precedence over ethical behavior, the importance of understanding ethical behavior becomes crucial. The ability of managers to recognize and deal with complex business ethical issues has become a significant priority for every company regardless of its type and size.

The aim of this paper was to analyze the ethical behavior of managers in a big company in Croatia. Research results show that this company does not have developed business ethics. Managers in everyday decision making tend to neglect ethics; it seems that they do not understand the importance of ethical behavior in business. Promoting ethical conduct and establishing and implementing ethical values, creating ethical business policies and strategies in a company needs to be implemented.

Benefits of business ethics are extremely high, while lack of ethics leads to a wealth of problems for a business. Ethical behavior of managers is directly related to company productivity and profitability through employee loyalty and morale, reputation of business from surrounding environments, positive public image etc. Therefore, managers in companies must understand and cherish business ethics, honesty and integrity; and make decisions with consistent ethical behavior. There is no doubt that the ethical behavior of decision makers is of strategic importance for successful business. Today, it is very challenging to have a successful business without effective and well-respected leader/s.

As noted in the introductory part of this paper, this research is justified because there is a lack of research into business ethics in Republic of Croatia, although this topic is a burning issue and is presented daily to the public and in the media. Therefore, regardless of its limitations, this research has provided some groundwork and opened up new issues in this area.

\section{References}

Aleksić, A., (2007). Business Ethics - an Element of Successful Business. The Proceedings of Zagreb Faculty of Economics and Business, V, pp.419-428.

Bazerman, M., Messick, D. and Stewart, L. (2007). Avoiding Ethical Danger Zones. Rotman Magazine

Buble, M. (2006.), Menadžment. Sveučilište u Splitu, Ekonomski fakultet, Split.

Drucker, P. F. (1954). The practice of management. New York, NY: Harper.

Emery, E. (2016). Ethical behaviour, Leadership, and Decision Making. Walden University, Doctoral Dissertation

Ferrell, O. C., Fraedrich, J. and Ferrell, L. (2005). Business Ethics, Ethical decision making and cases. Houghton Mifflin Company, Boston, New York.

Ivaniš, M. and Šturlić, M. R. (2016). Influence of Managers Personal Values and Ethical Behaviour on Business Success of Hotel Enterprises . Tourism \& Hospitality Industry 2016, Congress Proceedings, pp. 80-94

Jalšenjak, B. and Krkač, K. (2016). Poslovna etika, korporacijska društvena odgovornost $i$ održivost. Mate d.o.o., Zagreb.

Li, J., and Madsen, J. (2011). Business ethics and workplace guanxi in Chinese SOEs: A qualitative study. Journal of Chinese Human Resource Management, 2,pp. 83-99.

Sikavica, P.et al. (2014). Poslovno odlučivanje. Školska knjiga, Zagreb.

Stanaland, A. J., Lwin, M. O., and Murphy, P. E. (2011). Consumer perceptions of the antecedents and consequences of corporate social responsibility. Journal of Business Ethics, 102, pp. 47-55.

Suhonen et al., (2011). Organizational ethics: A literature review. Nursing Ethics, 18, pp. 285-303. 